\title{
An Assessment on the Coastal Seawater Quality of the Gulf of Suez, Egypt
}

\author{
Manal G. Mahmoud, Ehsan Abu El-Khir, Mahmoud H. Ebeid, Laila A. Mohamed*, \\ Mamdouh A. Fahmy, Kholoud S. Shaban
}

Marine Chemistry Laboratory, National Institute of Oceanography and Fisheries, Alexandria, Egypt

Email: *lailamsus@yahoo.com

How to cite this paper: Mahmoud, M.G., El-Khir, E.A., Ebeid, M.H., Mohamed, L.A., Fahmy, M.A. and Shaban, K.S. (2020) An Assessment on the Coastal Seawater Quality of the Gulf of Suez, Egypt. Journal of Environmental Protection, 11, 34-47. https://doi.org/10.4236/jep.2020.111004

Received: November 27, 2019

Accepted: January 16, 2020

Published: January 19, 2020

Copyright $\odot 2020$ by author(s) and Scientific Research Publishing Inc. This work is licensed under the Creative Commons Attribution International License (CC BY 4.0).

http://creativecommons.org/licenses/by/4.0/

\begin{abstract}
The present study focused on water quality assessment of 14 hotspot locations in the Gulf of Suez by measuring the physicochemical parameters seasonally during 2016 . The results of investigated area revealed that, the annual mean range of water was: temperature $\left(21.91^{\circ} \mathrm{C}-29.22^{\circ} \mathrm{C}\right), \mathrm{pH}(7.64-7.78)$, salinity (38.71\%o - 42.74\%o), dissolved oxygen $\left(6.09-8.78 \mathrm{mgO}_{2} / \mathrm{l}\right.$, ) oxidizable organic matter $(1.4-5.4 \mathrm{mg} / \mathrm{l})$, biological oxygen demand $(1.14-3.94$ $\left.\mathrm{mgO}_{2} / \mathrm{l}\right)$, total suspended solids (18.56 - $\left.37.69 \mathrm{mg} / \mathrm{l}\right)$, ammonia (13.51 - 494.41 $\mu \mathrm{g} / \mathrm{l})$, nitrite $(1.261-151.76 \mu \mathrm{g} / \mathrm{l})$, nitrate $(7.11-487.85)$, dissolved inorganic phosphate $(2.22$ - 53.26) and silicate $(19.83-347.61 \mu \mathrm{g} / \mathrm{l})$. The N:P ratio fluctuated between 4.21 and 1214.61 with the main value of 81.16 indicating that the different sites in the northern part of the Gulf of Suez are P-limited. Based on the Principal Component Analysis Data, the stations locating in the Northern and Southern side of the Gulf of Suez are relatively good water quality; meanwhile, water quality of the other stations locating in the northern side of the Gulf of Suez is found slightly polluted to a different degree coincided with an increase in the human activities in each of these locations.
\end{abstract}

\section{Keywords}

The Gulf of Suez, Seawater, Hydro-Chemical Parameter, Nutrients, Water Quality Index (WQI)

\section{Introduction}

Marine water quality is very important and critical due to its impact on human health and aquatic, including marine life [1] [2]. The water quality study is the strategy of deciding the chemical, physical, and biological distinctive of the possible contamination sources that degrade the quality of water determined by 
both natural and anthropogenic processes. Generally, water quality information is very important in supporting the planning and management of coastal and marine areas under the influence of massive human activities. The Gulf of Suez extends around $280 \mathrm{~km}$ toward the north, ending at the City of Suez, which is the entrance to the Suez Canal. It is relatively shallow, with a maximum depth of around $64 \mathrm{~m}$. It has a relatively flat base with a depth extending somewhere in the range of 55 and $73 \mathrm{~m} \mathrm{[3].} \mathrm{The} \mathrm{coastal} \mathrm{region} \mathrm{of} \mathrm{the} \mathrm{Gulf} \mathrm{of} \mathrm{Suez} \mathrm{is} \mathrm{one} \mathrm{of} \mathrm{the}$ most densely industrialized zones in Egypt. The sources and reasons of water contamination in the Gulf of Suez are exposed to different wellsprings of contamination that can be classified into sewage, organic solids, heavy metals, oils, nutrients, sediment mobilization, and litter. The mid-western side is situated under the immediate impact of sewage wastes and petrochemical effluents of the Ras-Gharib city. Whereas, the eastern (Sinai Peninsula) and southern (El Tour city) sides are affected by the human activities. Indeed, the water quality of the Gulf of Suez was monitored in previous studies [4] [5] [6] [7] [8]. The main objectives of the present study were set to study the water quality of the Gulf of Suez by measuring of physical and chemical characteristics; water temperature, dissolved oxygen (DO), oxidizable organic matter (OOM), $\mathrm{pH}$, salinity, ammonia, nitrite, nitrate, reactive phosphate and reactive silicate in surface water. Principal component analysis (PCA) was used to assess water quality in the Gulf of Suez as the main requirement for environmental and technical management of the Gulf of Suez, and consequently to minimize or mitigate the adverse environmental effects of human, industrial and maritime activities to allow sustainable use of the marine water resources.

\section{Materials and Methods}

\subsection{Study Area and Sampling}

Fourteen coastal sampling stations were selected to represent the different locations situated under the direct effect of human activities, public resort beaches and some protected area (Figure 1). Duplicate water samples from each station were collected seasonally during 2016 at $25 \mathrm{~cm}$ depth below the water surface to avoid the floating materials using a high quality and Purified PVC Niskin's bottle to estimate hydrochemical parameters (i.e., water temperature, salinity, $\mathrm{pH}$, dissolved oxygen) and eutrophication parameter (chlorophyll-a, nutrient salts).

\subsection{Sample Analysis}

The water sample was immediately sub-sampled for the following determinations in sequence as follows:

i) Water temperature, $\mathrm{pH}$ and salinity were measured using the Conductivity, Temperature, and Depth (CTD) (YSI 6000) after earlier calibration.

ii) Fixation of the Dissolved oxygen is commenced immediately in the field; samples for biochemical oxygen demand $\left(\mathrm{BOD}_{5}\right)$ were incubated in the laboratory for five days at $20^{\circ} \mathrm{C}$ and then determined by Winkler's method [9] [10]. 


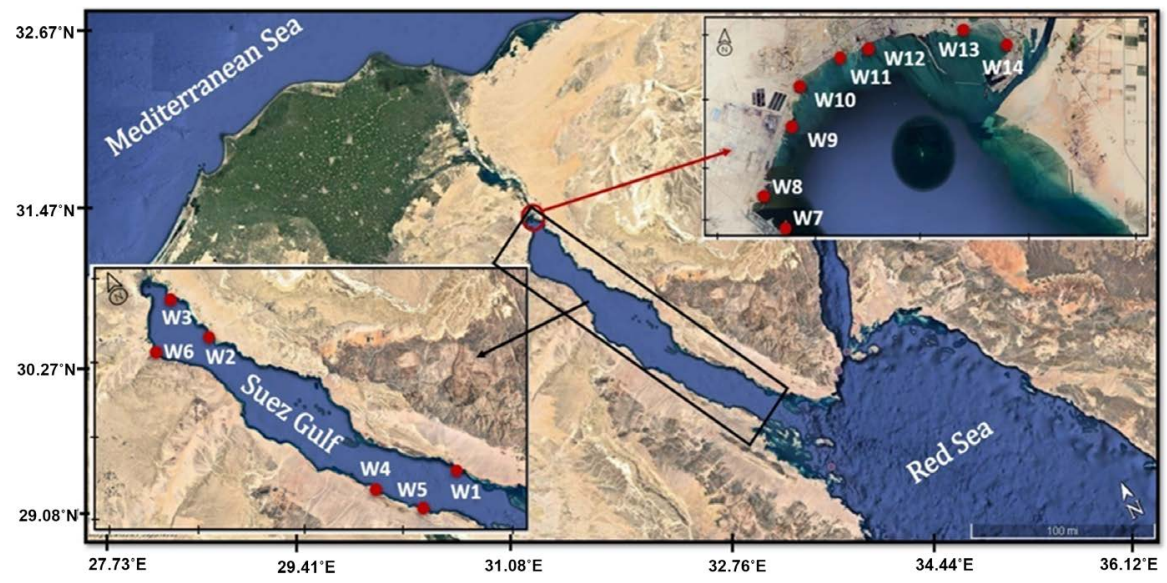

Station Key: W1: Al Tour; W2: Ras Safer; W3: Ayoon Moussa; W4: Ras Gharib; W5: Ras Shoquir; W6: Al-Ein El-Solhna; W7: Al-Dabyia; W8: Attaqa; W9: NIOF; W10: Power Station; W11: Al-Kabanoon; W12: Al-Zaitiyat; W13: Reax Beach; and W14: Port Tawfik.

Figure 1. Sampling locations along Gulf of Suez, Egypt.

iii) Oxidizable organic matter (OOM) was determined according to the method described by FAO (Food and Agriculture Organization) [11].

iv) Chlorophyll-a (Chl-a) was analyzed according to method given by Strickland and Parson's [9].

v) TSM was determined according to APHA (American Public Health Association) [12].

vi) Water samples for total ammonia nitrogen determination were fixed in the field and determined, using the indophenol blue technique [13].

vii) Dissolved inorganic-N (DIN) $\left(\mathrm{NO}_{2}-\mathrm{N}\right.$ and $\left.\mathrm{NO}_{3}-\mathrm{N}\right)$, reactive phosphate $\left(\mathrm{PO}_{4}^{3-}-\mathrm{P}\right)$ and silicate $\left(\mathrm{SiO}_{4}-\mathrm{Si}\right)$ were determined in filtered Seawater samples according to the methods described by Grasshoff et al. [11]

viii) DIN was calculated by summation of the inorganic-N forms:

$$
[\mathrm{DIN}]=\left[\mathrm{NO}_{3}-\mathrm{N}\right]+\left[\mathrm{NO}_{2}-\mathrm{N}\right]+\left[\mathrm{NH}_{4}^{+}-\mathrm{N}\right] .
$$

vi) $\mathrm{TN}$ and total phosphorus (TP) were determined according to the technique described by Koroleff [14] and modified by Valderrama [15].

The developed color was measured at different wavelengths using a spectrophotometer (JANEWAY6800 double-beam spectrophotometer). Synthetic samples and/or reference materials of different nutrient salts were used during analysis to get the calibration curve and for the precision and the accuracy as quality control tools.

\subsection{Statistical Analysis}

Principal component analysis (PCA), as a varimax rotated was performed with IBM-SPSS program (version 22) applying Kaiser Normalization.

\section{Results and Discussions}

The obtained data of hydrochemical characteristics of the present study are shown in (Figure 2) and illustrated in (Table 1) where these data demonstrating 

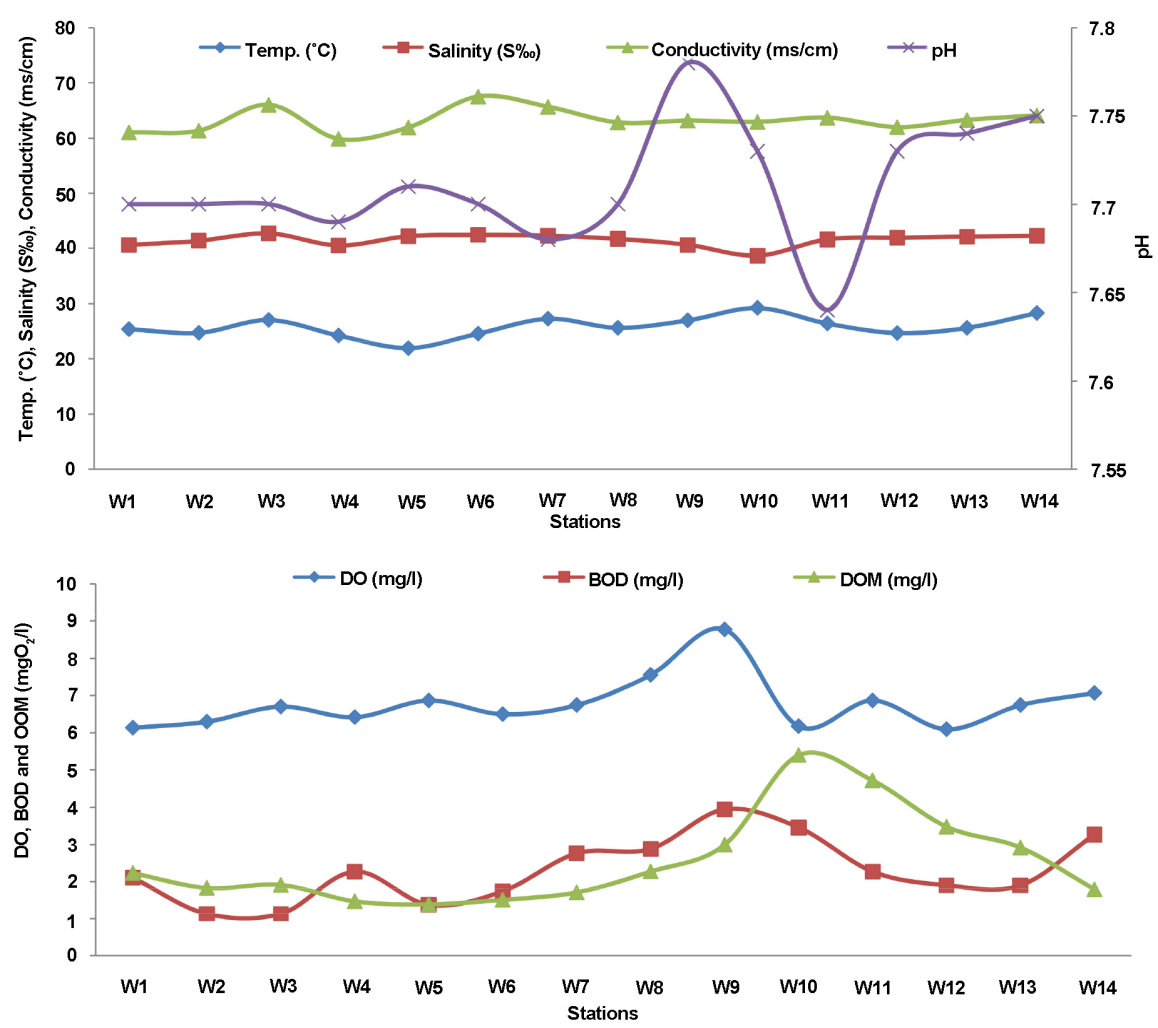

Figure 2. The distribution of regional variations averages of some hydrochemical characteristics of the Gulf of Suez surface coastal waters during 2016.

that water temperature fluctuated between $21.91^{\circ} \mathrm{C}-29.22^{\circ} \mathrm{C}, 38.71 \%$ - $42.74 \%$ o for salinity, $7.64-7.78$ for $\mathrm{pH}, 6.09-8.78 \mathrm{mg} / \mathrm{l}$ for $\mathrm{DO}, 1.14-3.94 \mathrm{mgO}_{2} / \mathrm{l}$ for BOD, $1.4-5.4 \mathrm{mgO}_{2} / \mathrm{l}$ for OOM. The annually averages for temperature, salinity, $\mathrm{pH}$, dissolved oxygen, biological oxygen demand, and oxidizable organic matter respectively, were found in agreement with UNEP and PERSGA [16]. Variations and fluctuation of salinity may be attributed to temperature and wastewater discharge. The seawater of the study area was found well-oxygenated; the relative increase in BOD at a station $\left(\mathrm{W}_{9}\right)$ could be the result of the relative increase of human impact at this location. Meanwhile, the presence of anthropogenic sources near to stations $\left(\mathrm{W}_{8}-\mathrm{W}_{13}\right)$ is responsible principally for the relative increase in the OOM. The data of the present study when compared with those of coastal water quality standards suited to marine ecosystem [17], revealed that the present status of the Gulf of Suez seawater is locating within these standards of the acceptable levels since it should be taken into account that permissible deviation is up to $>22$ from the normal temperature, $>0.2$ in $\mathrm{pH}$ unit, and $>5 \%$ overage seasonal salinity.

\subsection{Chlorophyll-a and Total Suspended Matter}

The regional values of chlorophyll-a, total suspended matter, and nutrient salts are presented graphically in (Figure 3 ) and illustrated in (Table 2). The absolute values varied between $0.11-3.66 \mu \mathrm{g} / \mathrm{l}$ for Chl-a and $18.56-37.69 \mathrm{mg} / \mathrm{l}$ for TSM 
Table 1. The absolute and average values of some hydrochemical parameters of surface coastal waters of the Gulf of Suez during 2016.

\begin{tabular}{|c|c|c|c|c|c|c|c|c|c|c|c|c|c|c|}
\hline \multirow[t]{2}{*}{ Code } & \multicolumn{2}{|c|}{ Temp. $\left({ }^{\circ} \mathrm{C}\right)$} & \multicolumn{2}{|c|}{ Salinity (S\%o) } & \multicolumn{2}{|c|}{$\begin{array}{l}\text { Conductivity } \\
(\mathrm{ms} / \mathrm{cm})\end{array}$} & \multicolumn{2}{|c|}{$\mathrm{pH}$} & \multicolumn{2}{|c|}{$\mathrm{DO}\left(\mathrm{mgO}_{2} / \mathrm{l}\right)$} & \multicolumn{2}{|c|}{$\mathrm{BOD}\left(\mathrm{mgO}_{2} / \mathrm{l}\right)$} & \multicolumn{2}{|c|}{$\mathrm{OOM}\left(\mathrm{mgO}_{2} / \mathrm{l}\right)$} \\
\hline & Min. & Max. & Min. & Max. & Min. & Max. & Min. & Max. & Min. & Max. & Min. & Max. & Min. & Max. \\
\hline \multirow{2}{*}{$\mathrm{W}_{1}$} & 21.41 & 27.77 & 40.29 & 40.93 & 55.98 & 64.25 & 7.38 & 8.02 & 5.53 & 6.83 & 1.14 & 3.58 & 1.44 & 3.20 \\
\hline & \multicolumn{2}{|c|}{25.36} & \multicolumn{2}{|c|}{40.61} & \multicolumn{2}{|c|}{60.99} & \multicolumn{2}{|c|}{7.7} & \multicolumn{2}{|c|}{6.13} & \multicolumn{2}{|c|}{2.11} & \multicolumn{2}{|c|}{2.24} \\
\hline \multirow{2}{*}{$\mathrm{W}_{2}$} & 20.53 & 31.09 & 39.98 & 42.27 & 56.32 & 69.78 & 7.41 & 8.00 & 5.69 & 7.15 & 0.98 & 1.30 & 1.44 & 2.88 \\
\hline & \multicolumn{2}{|c|}{24.7} & \multicolumn{2}{|c|}{41.4} & \multicolumn{2}{|c|}{61.31} & \multicolumn{2}{|c|}{7.7} & \multicolumn{2}{|c|}{6.3} & \multicolumn{2}{|c|}{1.14} & \multicolumn{2}{|c|}{1.84} \\
\hline \multirow{2}{*}{$\mathrm{W}_{3}$} & 18.41 & 35.67 & 42.38 & 42.94 & 54.93 & 77.27 & 7.46 & 7.98 & 4.71 & 7.80 & 0.65 & 1.95 & 1.28 & 2.72 \\
\hline & & & & & & & & & & & & & & \\
\hline & 18.95 & 28.57 & 40.08 & 41.62 & 52.87 & 66.21 & 7.41 & 7.91 & 5.69 & 7.64 & 0.98 & 4.06 & 0.48 & 2.88 \\
\hline & 18.59 & 27.81 & 40.24 & 42.01 & 53.23 & 72.21 & 7.45 & 8.02 & 6.01 & 7.80 & 0.98 & 1.95 & 0.96 & 2.24 \\
\hline$v_{5}$ & & & & & & & & & & & & & & \\
\hline & 19.64 & 29.54 & 39.30 & 45.60 & 52.72 & 89.54 & 7.44 & 7.97 & 5.85 & 7.31 & 1.46 & 2.11 & 0.64 & 2.24 \\
\hline 16 & & & & & & & & & & & & & & \\
\hline & 19.63 & 31.21 & 42.14 & 42.54 & 56.05 & 70.67 & 7.48 & 7.85 & 5.85 & 7.80 & 1.95 & 3.58 & 0.80 & 2.72 \\
\hline 107 & & & & & & & & & & & & & & \\
\hline & 18.85 & 29.47 & 41.23 & 42.10 & 54.95 & 68.04 & 7.49 & 7.87 & 6.18 & 8.78 & 2.28 & 3.74 & 1.28 & 3.04 \\
\hline & & & & & & & & & & & & & & \\
\hline & 19.39 & 31.26 & 38.28 & 41.81 & 55.37 & 69.73 & 7.31 & 8.26 & 7.64 & 10.08 & 2.44 & 7.31 & 1.60 & 4.32 \\
\hline & 21.04 & 35.86 & 33.21 & 42.13 & 46.73 & 76.13 & 7.54 & 8.10 & 5.36 & 6.50 & 2.11 & 6.18 & 2.56 & 8.00 \\
\hline & & & & & & & & & & & & & & \\
\hline & 19.36 & 31.35 & 41.33 & 41.95 & 54.97 & 70.16 & 7.53 & 7.81 & 5.69 & 8.45 & 1.14 & 3.25 & 1.92 & 10.40 \\
\hline & & & & & & & & & & & & & & \\
\hline & 19.51 & 28.08 & 41.86 & 42.09 & 55.76 & 66.27 & 7.56 & 7.85 & 5.53 & 6.83 & 1.30 & 2.28 & 1.76 & 7.20 \\
\hline W & & & & & & & & & & & & & & \\
\hline & 19.73 & 29.27 & 41.89 & 42.60 & 56.16 & 68.33 & 7.57 & 7.89 & 6.18 & 7.48 & 1.46 & 2.28 & 0.80 & 6.40 \\
\hline$v_{13}$ & & & & & & & & & & & & & & \\
\hline & 19.18 & 31.16 & 41.80 & 42.62 & 55.74 & 70.89 & 7.57 & 7.91 & 5.69 & 8.45 & 1.14 & 6.74 & 0.48 & 2.88 \\
\hline$W_{14}$ & & & & & & & & & & & & & & \\
\hline Min. & & & 38 & & & & & & & & & & & \\
\hline Max. & & & 42 & & & & & & & & & & & \\
\hline Average & & & 41 & & & & & & & & & & & \\
\hline
\end{tabular}

giving the overall averages 0.98 and 26.15 for Chl-a and TSM respectively. An enrichment of DIN was correlated positively to the amounts with Chl-a, meanwhile, the present results clearly showed peaks in Chl-a with increasing temperature. The relative increase in TSM at a station $\left(\mathrm{W}_{10}\right)$ since it was subjected to 

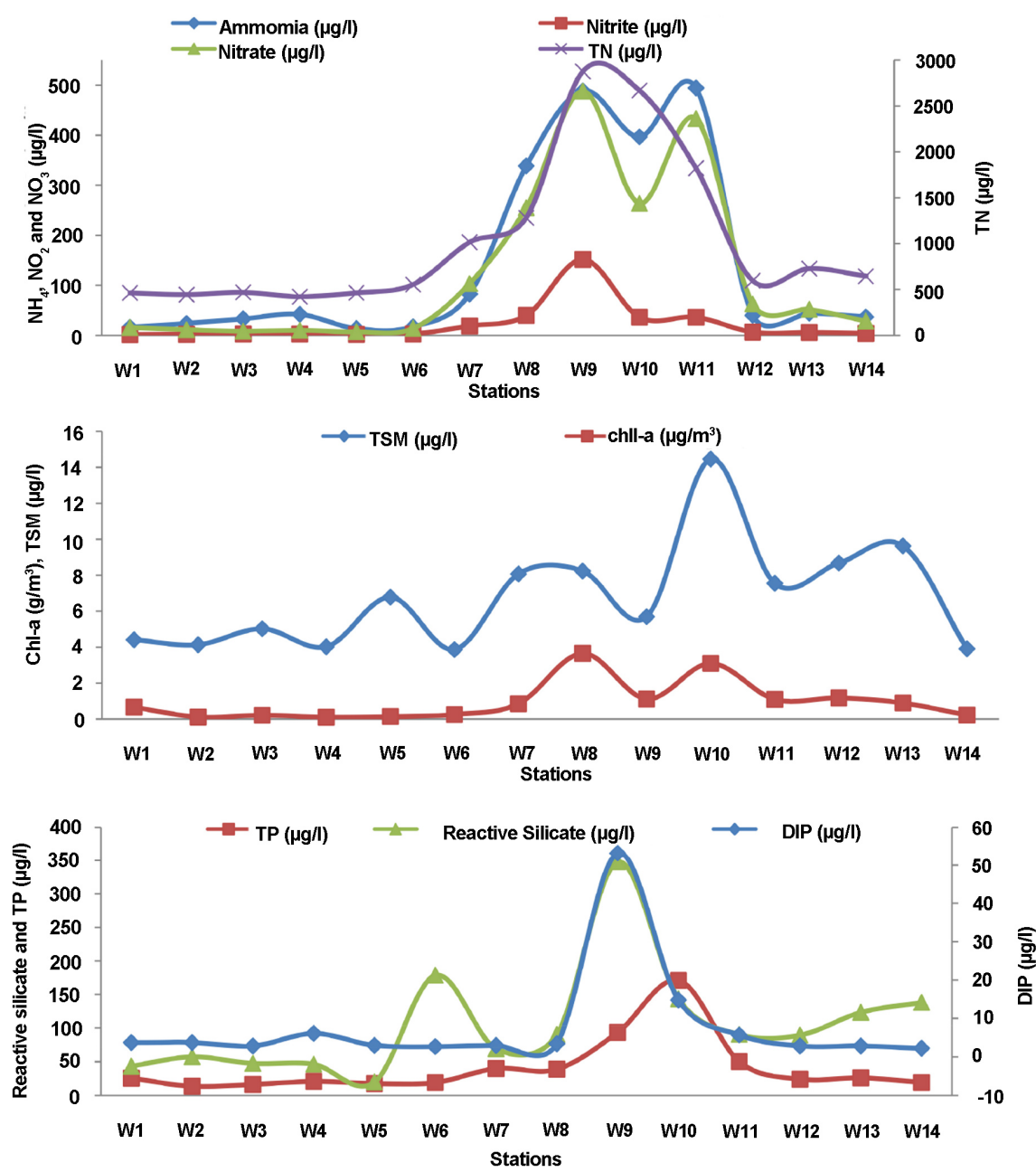

Figure 3. The distribution of regional variations averages of nutrient salts, Chl-a, and TSM of the Gulf of Suez surface coastal waters during 2016.

high amounts of effluents. The seasonal variations in TSM values pointed out that an increase in water temperature has coincided with an increase of TSM where suspended particulate matter contributed to a big extent in relating the heat.

\subsection{Nutrient Salts}

The obtained levels of nitrogen and phosphorus forms are given in (Table 2) and demonstrating graphically at (Figure 3). The results deduced that the absolute values varied between 13.51 - $494.41 \mu \mathrm{g} / \mathrm{l}$ for ammonium, 1.61 - $151.76 \mu \mathrm{g} / \mathrm{l}$ $\mathrm{NO}_{2}-\mathrm{N}$ for nitrite and $7.11-487.85 \mu \mathrm{g} / \mathrm{N} \mathrm{NO}_{3}-\mathrm{N}$ for nitrate giving the overall means $147.72 \mu \mathrm{g} / \mathrm{l} \mathrm{NH} \mathrm{NH}_{4}-\mathrm{N}, 22.47 \mu \mathrm{g} / \mathrm{l} \mathrm{NO}_{2}-\mathrm{N}$ and $125.22 \mu \mathrm{g} / \mathrm{l} \mathrm{NO}_{3}-\mathrm{N}$. The result demonstrated that $50 \%, 7.60 \%$ and $42.4 \%$ for $\mathrm{NH}_{4}-\mathrm{N}, \mathrm{NO}_{2}-\mathrm{N}$, and $\mathrm{NO}_{3}-\mathrm{N}$ of the DIN in the Gulf of Suez surface coastal waters, respectively. Variations in the amounts of different DIN forms could be accompanied by the relative increase or decrease in human activity and/or discharged effluents, up to taking rate by phytoplankton and nitrification or denitrification processes in the study area. 
Table 2. The values of chlorophyll-a, total suspended maters and nutrient salts of coastal waters of the Gulf of Suez during 2016.

\begin{tabular}{|c|c|c|c|c|c|c|c|c|c|c|c|c|c|c|c|c|c|c|}
\hline \multirow[t]{2}{*}{ Code } & \multicolumn{2}{|c|}{ Chl-a $\left(\mu \mathrm{g} / \mathrm{m}^{3}\right)$} & \multicolumn{2}{|c|}{ TSM (mg/l) } & \multicolumn{2}{|c|}{$\mathrm{NH}_{4}(\mu \mathrm{g} / \mathrm{l})$} & \multicolumn{2}{|c|}{$\mathrm{NO}_{2}(\mu \mathrm{g} / \mathrm{l})$} & \multicolumn{2}{|c|}{$\mathrm{NO}_{3}(\mu \mathrm{g} / \mathrm{l})$} & \multicolumn{2}{|c|}{$\mathrm{TN}(\mu \mathrm{g} / \mathrm{l})$} & \multicolumn{2}{|c|}{$\mathrm{PO}_{4}(\mu \mathrm{g} / \mathrm{l})$} & \multicolumn{2}{|c|}{$\mathrm{TP}(\mu \mathrm{g} / \mathrm{l})$} & \multicolumn{2}{|c|}{$\mathrm{SiO}_{4}(\mu \mathrm{g} / \mathrm{l})$} \\
\hline & Min. & Max. & Min. & Max. & Min. & Max. & Min. & Max. & Min. & Max. & Min. & Max. & Min. & Max. & Min. & Max. & Min. & Max. \\
\hline \multirow{2}{*}{$\mathrm{W}_{1}$} & 0.22 & 1.11 & 0.01 & 17.60 & 10.64 & 28.56 & 1.12 & 2.10 & 2.88 & 32.71 & 48.13 & 1424.53 & 2.38 & 4.76 & 14.28 & 34.03 & 23.39 & 59.76 \\
\hline & \multicolumn{2}{|c|}{0.67} & \multicolumn{2}{|c|}{24.21} & \multicolumn{2}{|c|}{16.31} & \multicolumn{2}{|c|}{1.61} & \multicolumn{2}{|c|}{15.72} & \multicolumn{2}{|c|}{463.37} & \multicolumn{2}{|c|}{3.71} & \multicolumn{2}{|c|}{25.65} & \multicolumn{2}{|c|}{43.32} \\
\hline \multirow{2}{*}{$\mathrm{W}_{2}$} & 0.00 & 0.25 & 0.01 & 16.50 & 4.20 & 65.24 & 1.68 & 3.08 & 7.42 & 14.06 & 64.94 & 1327.20 & 1.18 & 6.55 & 7.50 & 25.00 & 36.38 & 96.79 \\
\hline & \multicolumn{2}{|c|}{0.12} & \multicolumn{2}{|c|}{22.88} & 23. & .94 & 2. & 24 & 11 & 26 & & 4.08 & 3.7 & 72 & 13 & 68 & & 16 \\
\hline & 0.10 & 0.44 & 0.01 & 20.04 & 10.36 & 83.44 & 2.66 & 3.50 & 5.23 & 11.33 & 67.95 & 1362.59 & 2.36 & 3.57 & 11.90 & 18.75 & 29.23 & 87.70 \\
\hline & & & & & 32. & 97 & 2. & 94 & 8 & 3 & & 9.03 & 2.8 & 82 & 16 & 43 & & 31 \\
\hline & 0.00 & 0.21 & 0.01 & 16.06 & 8.40 & 108.36 & 1.96 & 4.48 & 8.24 & 13.66 & 72.02 & 1128.12 & 2.38 & 11.90 & 15.48 & 30.55 & 36.54 & 51.97 \\
\hline 4 & & & & & 42 & & 2 & & 10 & 17 & & 2.05 & 6.0 & 08 & 20 & 81 & & 16 \\
\hline & 0.00 & 0.24 & 0.01 & 27.08 & 6.16 & 22.12 & 0.98 & 2.66 & 3.49 & 10.81 & 52.91 & 1216.60 & 1.79 & 4.71 & 12.96 & 23.21 & 11.04 & 29.88 \\
\hline & & & & & 13. & 51 & 2. & 3 & 7. & 11 & & 4.12 & 2.9 & 96 & & .9 & & 83 \\
\hline & 0.12 & 0.44 & 0.01 & 15.43 & 6.16 & 26.04 & 1.12 & 4.20 & 3.50 & 18.69 & 50.61 & 1632.46 & 1.79 & 3.53 & 10.91 & 26.39 & 142.38 & 225.41 \\
\hline$N_{1}$ & & & & & 17. & 01 & 3. & & 14 & 05 & & 4.15 & 2.6 & 67 & 15 & .2 & & 3.51 \\
\hline & 0.23 & 1.43 & 0.01 & 32.23 & 28.84 & 140.56 & 5.74 & 44.80 & 46.47 & 197.26 & 80.87 & 3167.58 & 1.79 & 3.57 & 26.78 & 60.70 & 41.57 & 113.68 \\
\hline 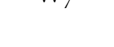 & & & & & 82. & 67 & 18 & & 103 & .58 & & 6.06 & 2.9 & 97 & 39 & 93 & & 19 \\
\hline & 0.61 & 9.67 & 0.01 & 32.85 & 253.96 & 538.72 & 24.78 & 52.08 & 123.37 & 509.29 & 117.86 & 3809.06 & 1.79 & 4.17 & 30.55 & 63.09 & 51.97 & 135.12 \\
\hline r & & & & & 338 & .45 & 39 & & 254 & .98 & & 0.93 & 3.4 & & 38 & .9 & & .24 \\
\hline $\mathrm{W}_{9}$ & 0.45 & 1.57 & 0.01 & 22.74 & 210.00 & 899.64 & 34.86 & 424.34 & 223.37 & 919.81 & 151.12 & 5791.02 & 2.38 & $\begin{array}{c}202.3 \\
7\end{array}$ & 41.66 & 241.65 & 62.36 & $\begin{array}{c}1015.9 \\
7\end{array}$ \\
\hline & & & & & 488 & .67 & 151 & .76 & 487 & .85 & & 7.64 & 53.2 & & 93 & 35 & & 7.61 \\
\hline & 0.87 & 5.96 & 0.01 & 57.74 & 89.60 & 883.12 & 16.24 & 57.12 & 95.10 & 397.66 & 119.45 & 8976.30 & 2.38 & 41.23 & 63.19 & 458.30 & 58.46 & 263.97 \\
\hline 10 & & & & & 396 & 83 & 36 & & & .77 & & 9.44 & 14.7 & & 170 & .82 & & .13 \\
\hline $\mathrm{W}_{\mathrm{u}}$ & 0.00 & 2.66 & 0.02 & 30.14 & 51.52 & 897.40 & 5.74 & 64.12 & 16.28 & $\begin{array}{c}1252.3 \\
7\end{array}$ & 79.28 & 3609.98 & 1.79 & 14.28 & 19.10 & 122.91 & 64.96 & 116.28 \\
\hline & & & & & 494 & .41 & 36 & & 432 & .77 & & 3.13 & 5.6 & & 50 & 23 & & 38 \\
\hline & 0.87 & 1.75 & 0.01 & 34.63 & 20.44 & 64.96 & 3.78 & 12.74 & 17.33 & 102.51 & 62.64 & 1667.85 & 2.38 & 3.53 & 14.32 & 32.64 & 55.22 & 120.18 \\
\hline 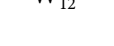 & & & & & 40. & .04 & 6. & & & 93 & & 6.4 & 2.8 & & 24 & 17 & & .36 \\
\hline & 0.46 & 1.32 & 0.01 & 38.43 & 12.60 & 78.68 & 3.92 & 11.48 & 9.48 & 139.05 & 63.00 & 2234.12 & 2.38 & 2.98 & 20.46 & 40.28 & 55.87 & 203.49 \\
\hline 13 & & & & & 44. & 31 & 5. & & 52 & .02 & & 7.57 & 2.8 & & 26 & 25 & & .14 \\
\hline & 0.10 & 0.46 & 0.01 & 15.62 & 13.44 & 47.60 & 2.38 & 6.72 & 18.27 & 46.28 & 39.99 & 1849.23 & 1.19 & 2.98 & 13.89 & 27.78 & 55.22 & 237.10 \\
\hline 14 & & & & & 36. & 89 & 4. & & 28 & .51 & & 5.24 & 2.2 & & 19 & 21 & & .96 \\
\hline Min. & & & & & 13. & 51 & 1. & & 7. & 11 & & 2.05 & 2.2 & & 13 & 68 & & .83 \\
\hline Max. & & & & & 494 & .41 & 151 & .76 & 487 & .85 & & 7.64 & 53.2 & & 170 & .82 & & .61 \\
\hline Average & 0. & & & & 147 & .72 & 22 & & 125 & 22 & & 2.37 & 7.8 & & 41 & 18 & & .95 \\
\hline
\end{tabular}

Total nitrogen showed a fluctuation between 422.05 - $2877.64 \mu \mathrm{g} / \mathrm{l}-\mathrm{N}$ giving an overall mean value nutrient salts $1032.37 \mu \mathrm{g} / \mathrm{l}-\mathrm{N}$. The absolute values of DIP and $\mathrm{TP}$ varied between 2.22 - $53.26 \mu \mathrm{g} / \mathrm{l}$ for $\mathrm{PO}_{4}-\mathrm{P}$ and $13.68-170.82 \mu \mathrm{g} / \mathrm{l}$ for $\mathrm{TP}$ 
giving the overall means $7.85 \mu \mathrm{g} / \mathrm{l}$ and $41.18 \mu \mathrm{g} / \mathrm{l}$ for dissolved inorganic phosphorus and total phosphorus in the Gulf of Suez surface coastal waters, respectively. Variations in DIP values could be controlled by the interplay of physical (upwelling, relaxation events) and biological action (DIP uptake) (agreed with the value determined by Ruttenberg and Dyhrman [18] [19]. The current study represented that an increase in the amounts of total nitrogen and total phosphorus was accompanied by a decrease in salinity values. This illustrates the role of industrial and sewage effluents in providing the coastal seawater with nitrogen and phosphorus forms. The DIN/DIP ratios showed very wide fluctuations ranging from $4.21-1214$ giving the overall mean nutrient salts. They deviate from that of the normal case of the Red field (N/P is 16:1) coincided with the relative increase of anthropogenic activity. The results determined by Chraudani and Vighi [20], indicated that the marine algae are P-limited at P:N ratio $<6$ and $\mathrm{N}$-Limited at ratio > 4.5; in the range of $4.5-6$; the two nutrients are close to their optimum assimilative proportion. Extremely variability of the N/P ratio is omitted to a land-based runoff as mentioned by Dorgham et al. [21]. Based on the measurement of TN $(1.3 \mathrm{mg} / \mathrm{l})$, TP $(41.18 \mu \mathrm{g} / \mathrm{l})$ and Chl-a $(0.97 \mu \mathrm{g} / \mathrm{l})$, classification of eutrophication status of Suez Gulf seawaters was done according to Håkanson, L. [22] they signified that Suez Gulf is locating within hypertrophic state based on TN and TP and oligotrophic state based on Chl-a $(>1.0 \mu \mathrm{g} / \mathrm{l})$ $(<0.40 \mathrm{mg} / \mathrm{l})$. The levels of reactive silicate varied between $19.83-347.61 \mu \mathrm{g} / \mathrm{l}$ $\mathrm{SiO}_{4}$-Si giving an overall value silicate $105.95 \mu \mathrm{g} / 1 \mathrm{SiO}_{4}$-Si for the Gulf of Suez surface coastal water. High fluctuation in the values could be associated with the physical mixing of seawater with freshwater, adsorption auto-sedimentary particles, chemical interaction with clay minerals, co-precipitation with humic constituents in addition to the biological removed by phytoplankton especially diatoms and silicoflagellutes.

An assessment of the eutrophication status of waters of the Gulf of Suezhas been based on the principal component analysis. The Eutrophication Index is calculated according to the following formula [23],

$$
\text { E.I. }=\mathrm{aC}_{\mathrm{PO}_{4}}+\mathrm{bC}_{\mathrm{NO}_{3}}+\mathrm{cC}_{\mathrm{NO}_{2}}+\mathrm{dC}_{\mathrm{NH}_{3}}+\mathrm{eC}_{\mathrm{Chl}-\mathrm{a}}
$$

where, $\mathrm{C}$ is the concentrations and $\mathrm{a}, \mathrm{b}, \mathrm{c}, \mathrm{d}$ and e are the coefficients derived from PCA analysis for the first component analysis. The coefficients of the five variables in the first principal component are displayed in (Table 3). The application of frequency distribution analysis represents the ranges of the eutrophication index as oligotrophic, mesotrophy and eutrophication as mentioned by Ignatiades et al. [24] (Table 4). The Enrichment index values for the fourteen stations of the Gulf of Suez seawaters are given in (Figure 4). The results demonstrate that the coastal seawaters of the Gulf of Suez varied from oligotrophy (0.02) at station $\mathrm{W}_{5}$ to eutrophication (1.117) at station $\mathrm{W}_{9}$, the average value of enrichment index (0.26) indicates that the coastal water of the Gulf of Suez is oligotrophy. Stations $\mathrm{W}_{9}$ and $\mathrm{W}_{11}$ are grouped as Eutrophication, stations, while stations $\mathrm{W}_{8}$ and $\mathrm{W}_{10}$ are grouped as mesotrophy and the rest of stations are 
Table 3. The coefficients of the first principal component for five variables concentrations from the coastal waters of the Gulf of Suez.

\begin{tabular}{cc}
\hline Variables & Coefficients \\
\hline Nitrate & 0.962 \\
Ammonia & 0.943 \\
Nitrite & 0.934 \\
Phosphate & 0.828 \\
Chl-a & 0.584 \\
\hline
\end{tabular}

Table 4. Ranges of the Eutrophication index "Oligtrophy, Mesotrophy and Eutrophication" resulting from the application of frequency distribution analysis.

\begin{tabular}{ccc}
\hline Trophic status & Lower limit & Upper limit \\
\hline Oligtrophy & 0.04 & 0.38 \\
Mesotrophy & 0.37 & 0.87 \\
Eutrophication & 0.83 & 1.51 \\
\hline
\end{tabular}
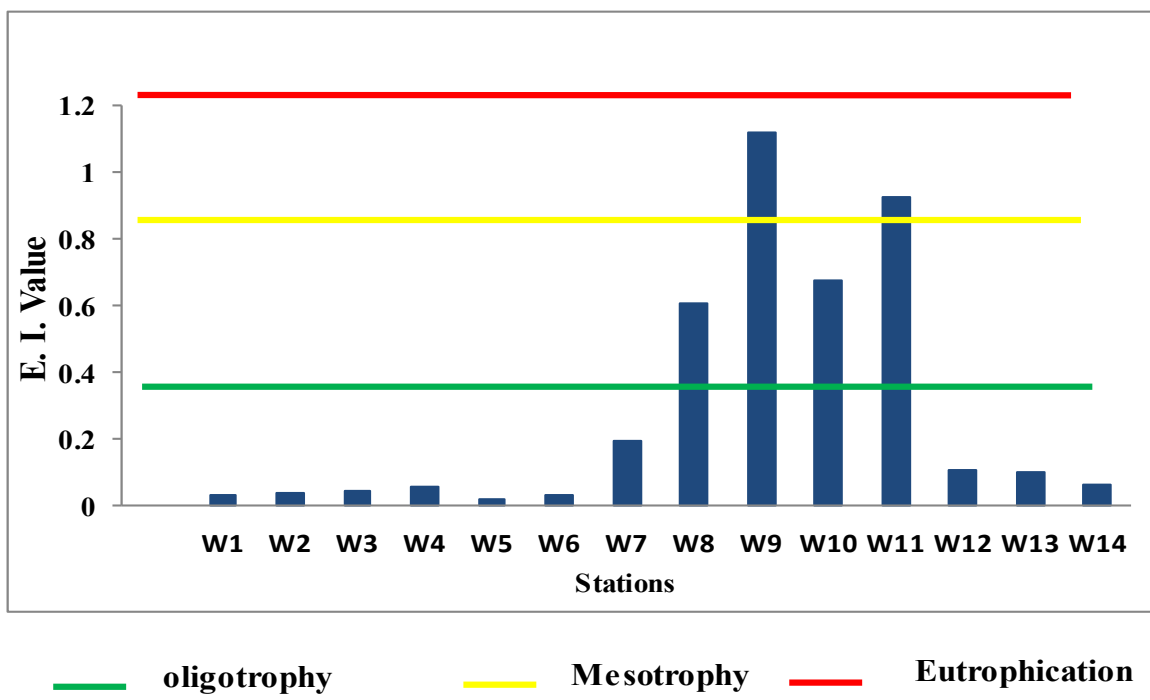

Mesotrophy

Eutrophication

Figure 4. The Enrichment index values for the fourteen stations of the coastal seawaters of the Gulf of Suez.

oligotrophy. The Enrichment index values of $\mathrm{W}_{8}, \mathrm{~W}_{9}, \mathrm{~W}_{10}$, and $\mathrm{W}_{11}$ indicate an increase of the drainage effluents at these locations.

\subsection{Statistical Analysis}

A correlation matrix was displayed for surface coastal waters of the Gulf of Suez (Table 5) at $\mathrm{N}=14, \mathrm{r}$ is significant when it will be higher than 0.51 . Correlation coefficient signified positive relationship between water temperature with each of BOD (0.58), DOM (0.60), $\mathrm{NH}_{4}-\mathrm{N}$ (0.55), TN (0.67) and TP (0.71). An increase in temperature leads to an increase in the respiration of aquatic organisms and 
Table 5. Pearson correlation matrix for all investigated environmental parameters.

\begin{tabular}{|c|c|c|c|c|c|c|c|c|c|c|c|c|c|c|c|c|}
\hline & $\begin{array}{l}\text { Temp. } \\
\left({ }^{\circ} \mathrm{C}\right)\end{array}$ & $\begin{array}{c}\text { Salinity } \\
(\mathrm{S} \%)\end{array}$ & $\begin{array}{c}\text { Conductivity } \\
(\mathrm{ms} / \mathrm{cm})\end{array}$ & $\mathrm{pH}$ & $\begin{array}{c}\text { Do } \\
(\mathrm{mg} / \mathrm{l})\end{array}$ & $\begin{array}{c}\mathrm{BOD} \\
(\mathrm{mg} / \mathrm{l})\end{array}$ & $\begin{array}{l}\mathrm{DOM} \\
(\mathrm{mg} / \mathrm{l})\end{array}$ & $\begin{array}{c}\text { chl-a } \\
\left(\mu \mathrm{g} / \mathrm{m}^{3}\right)\end{array}$ & $\begin{array}{l}\text { TSM } \\
(\mu \mathrm{g} / \mathrm{l})\end{array}$ & $\begin{array}{c}\mathrm{NH}_{4} \\
(\mu \mathrm{g} / \mathrm{l})\end{array}$ & $\begin{array}{c}\mathrm{NO}_{2} \\
(\mu \mathrm{g} / \mathrm{l})\end{array}$ & $\begin{array}{l}\mathrm{NO}_{3} \\
(\mu \mathrm{g} / \mathrm{l})\end{array}$ & $\begin{array}{c}\mathrm{TN} \\
(\mu \mathrm{g} / \mathrm{l})\end{array}$ & $\begin{array}{c}\mathrm{PO}_{4} \\
(\mu \mathrm{g} / \mathrm{l})\end{array}$ & $\begin{array}{c}\mathrm{TP} \\
(\mu \mathrm{g} / \mathrm{l})\end{array}$ & $\begin{array}{r}\mathrm{SiO}_{4} \\
(\mu \mathrm{g} / \mathrm{l})\end{array}$ \\
\hline Temp. $\left({ }^{\circ} \mathrm{C}\right)$ & 1 & & & & & & & & & & & & & & & \\
\hline Salinity (S\%o) & -0.269 & 1 & & & & & & & & & & & & & & \\
\hline $\begin{array}{l}\text { Conductivity } \\
(\mathrm{ms} / \mathrm{cm})\end{array}$ & 0.34 & 0.56 & 1 & & & & & & & & & & & & & \\
\hline $\mathrm{pH}$ & 0.10 & -0.17 & -0.08 & 1 & & & & & & & & & & & & \\
\hline Do (mg/l) & 0.14 & 0.06 & 0.14 & 0.39 & 1 & & & & & & & & & & & \\
\hline $\mathrm{BOD}(\mathrm{mg} / \mathrm{l})$ & 0.58 & -0.43 & - & 0.42 & 0.56 & 1 & & & & & & & & & & \\
\hline $\operatorname{DOM}(\mathrm{mg} / \mathrm{l})$ & 0.60 & -0.51 & -0.08 & 0.01 & -0.046 & 0.39 & 1 & & & & & & & & & \\
\hline chl-a $\left(\mu \mathrm{g} / \mathrm{m}_{3}\right)$ & 0.48 & -0.41 & -0.06 & 0.04 & 0.18 & 0.52 & 0.58 & 1 & & & & & & & & \\
\hline $\operatorname{TSM}(\mu \mathrm{g} / \mathrm{l})$ & 0.49 & -0.44 & -0.02 & 0.07 & -0.115 & 0.33 & 0.75 & 0.72 & 1 & & & & & & & \\
\hline $\mathrm{NH}_{4}(\mu \mathrm{g} / \mathrm{l})$ & 0.55 & -0.43 & 0.01 & -0.022 & 0.56 & 0.65 & 0.71 & 0.64 & 0.45 & 1 & & & & & & \\
\hline $\mathrm{NO}_{2}(\mu \mathrm{g} / \mathrm{l})$ & 0.40 & -0.31 & 0.02 & 0.40 & 0.84 & 0.69 & 0.33 & 0.34 & 0.14 & 0.77 & 1 & & & & & \\
\hline $\mathrm{NO}_{3}(\mu \mathrm{g} / \mathrm{l})$ & 0.50 & -0.34 & 0.03 & 0.02 & 0.64 & 0.66 & 0.65 & 0.54 & 0.37 & 0.97 & 0.84 & 1 & & & & \\
\hline $\mathrm{TN}(\mu \mathrm{g} / \mathrm{l})$ & 0.67 & -0.56 & 0.06 & 0.24 & 0.54 & 0.76 & 0.71 & 0.60 & 0.55 & 0.92 & 0.83 & 0.90 & 1 & & & \\
\hline $\mathrm{PO}_{4}(\mu \mathrm{g} / \mathrm{l})$ & 0.31 & -0.41 & -0.06 & 0.54 & 0.74 & 0.62 & 0.27 & 0.16 & 0.06 & 0.62 & 0.95 & 0.70 & 0.76 & 1 & & \\
\hline $\mathrm{TP}(\mu \mathrm{g} / \mathrm{l})$ & 0.71 & -0.76 & -0.01 & 0.25 & 0.17 & 0.67 & 0.75 & 0.64 & 0.72 & 0.71 & 0.55 & 0.63 & 0.88 & 0.55 & 1 & \\
\hline $\mathrm{SiO}_{4}(\mu \mathrm{g} / \mathrm{l})$ & 0.38 & -0.15 & 0.28 & 0.61 & 0.70 & 0.66 & 0.27 & 0.18 & 0.06 & 0.54 & 0.83 & 0.62 & 0.69 & 0.84 & 0.481 & 1 \\
\hline
\end{tabular}

consequently decomposition of organic matter. Salinity was correlated negatively with each of TN $(-0.56)$ and TP $(-0.763)$ which gives an indication to the rule of effluents in increasing the levels for each of TN $+\mathrm{TP}$. DOM was correlated positively with each of Chl-a (0.58), TSM (0.75), $\mathrm{NH}_{4}(0.71), \mathrm{NO}_{3}(0.65), \mathrm{TN}$ (0.71) and TP (0.75). An elevation of organic matter with an increase in TSM contents may give an indication of the importance of the adsorption process of organic matter onto TSM. A positive correlation between nutrients with each other and oxidizable organic matter revealed that they have the same source.

Analyzing the data was performed according to the principal component analysis using the statistical package for the social sciences SPSS [25]. The output data showed four factors with eigenvalues higher than one, which affected water parameters distribution, association and sources with cumulative covariance of 87.51\% (Table 6, Figure 5).

Principle component analysis was applied to evaluate Water Quality Index ( $W Q I$ ) at each station and to determine the hot spot stations. WQI was calculated according to the following formula [26],

$$
W Q I=\sum_{n=1}^{n}\left(\frac{\lambda n}{\Sigma \lambda}\right) \times P C n
$$

where: $n$ is the number of effective components, $\lambda n$ : are the Eigenvalues of the effective components, $\Sigma \lambda$ : the sum of the Eigenvalues and PCn: the n critical principal component scores. High values of the principal component factor 
Table 6. Varimax rotated component matrix for coastal seawater of the Gulf of Suez.

\begin{tabular}{|c|c|c|c|c|}
\hline \multirow{2}{*}{ Parameters } & \multicolumn{4}{|c|}{ Component } \\
\hline & $\mathrm{PC}_{1}$ & $\mathrm{PC}_{2}$ & $\mathrm{PC}_{3}$ & $\mathrm{PC}_{4}$ \\
\hline Temp & & 0.74 & & \\
\hline Salinity & & -0.563 & 0.71 & \\
\hline Conductivity & & & 0.95 & \\
\hline $\mathrm{pH}$ & & & & 0.91 \\
\hline DO & 0.91 & & & \\
\hline BOD & 0.61 & & & \\
\hline $\mathrm{OM}$ & & 0.86 & & \\
\hline Chl-a & & 0.76 & & \\
\hline TSM & & 0.891 & & \\
\hline Ammonia & 0.73 & 0.61 & & \\
\hline Nitrite & 0.94 & & & \\
\hline Nitrate & 0.82 & 0.505 & & \\
\hline $\mathrm{TN}$ & 0.71 & 0.68 & & \\
\hline $\mathrm{PO}_{4}$ & 0.86 & & & \\
\hline $\mathrm{TP}$ & & 0.86 & & \\
\hline Silicate & 0.77 & & & \\
\hline Eigen Values & 0.59 & 0.21 & 0.12 & 0.08 \\
\hline Variance & 51.94 & 17.98 & 10.21 & 7.39 \\
\hline CV \% & 51.94 & 69.92 & 80.13 & 87.51 \\
\hline
\end{tabular}

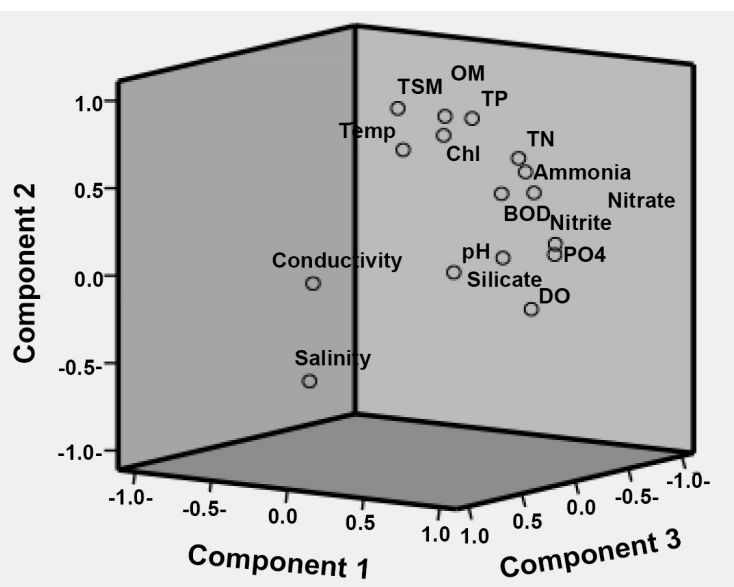

Figure 5. Component plot of factors 1, 2, 3 in rotated space for the seasonal averages of studied parameters in Seawater of the Gulf of Suez during 2016.

scores mean that this station is situated under hot spot conditions. Data on water quality of the Gulf of Suez are shown in (Table 7); a positive value of WQI indicates pollution. They demonstrated that stations locating in the Northern and Southern side of the Gulf of Suez are relatively good and varied between $(-0.07),(-0.55)$, meanwhile, water quality of the other stations locating in the northern side of Suez Gulf $\left(\mathrm{W}_{7}, \mathrm{~W}_{8}, \mathrm{~W}_{9}, \mathrm{~W}_{10}, \mathrm{~W}_{11}, \mathrm{~W}_{14}\right)$ are found slightly 
Table 7. Principal component factor scores and water quality index (WQI) of the Gulf of Suez Seawater.

\begin{tabular}{cccccc}
\hline Code & PC1 & PC2 & PC3 & PC4 & WQI \\
\hline $\mathrm{W}_{1}$ & -0.61 & -0.3 & -1.06 & 0.05 & -0.55 \\
$\mathrm{~W}_{2}$ & -0.45 & -0.76 & -0.77 & -0.32 & -0.54 \\
$\mathrm{~W}_{3}$ & -0.51 & -0.36 & 1.45 & -0.15 & -0.22 \\
$\mathrm{~W}_{4}$ & -0.29 & -0.81 & -1.59 & -0.13 & -0.53 \\
$\mathrm{~W}_{5}$ & -0.35 & -0.97 & -1.09 & -0.23 & -0.55 \\
$\mathrm{~W}_{6}$ & -0.22 & -0.68 & 1.57 & 0.21 & -0.07 \\
$\mathrm{~W}_{7}$ & -0.23 & 0.25 & 1.31 & -0.35 & $\mathbf{0 . 0 4}$ \\
$\mathrm{W}_{8}$ & $\mathbf{0 . 6 1}$ & $\mathbf{0 . 4}$ & 0 & -1.05 & $\mathbf{0 . 3 6}$ \\
$\mathrm{W}_{9}$ & $\mathbf{3 . 1}$ & -0.21 & -0.27 & $\mathbf{1 . 2 3}$ & $\mathbf{1 . 8 7}$ \\
$\mathrm{W}_{10}$ & -0.48 & $\mathbf{2 . 9 9}$ & -0.59 & $\mathbf{0 . 9 4}$ & $\mathbf{0 . 3 4}$ \\
$\mathrm{W}_{11}$ & $\mathbf{0 . 8 5}$ & $\mathbf{0 . 7 4}$ & $\mathbf{0 . 2 1}$ & -2.61 & $\mathbf{0 . 4 6}$ \\
$\mathrm{W}_{12}$ & -0.76 & 0.17 & -0.3 & 0.38 & -0.42 \\
$\mathrm{~W}_{13}$ & -0.58 & 0.13 & 0.38 & 0.76 & -0.2 \\
$\mathrm{~W}_{14}$ & -0.1 & -0.59 & $\mathbf{0 . 7 4}$ & $\mathbf{1 . 2 7}$ & $\mathbf{0 . 0 1}$ \\
\hline
\end{tabular}

polluted to a different degrees (0.04) - (1.87) coincided with an increase in the human activities in each of these locations. W7 is located in Al Adabbia Harbour and $\mathrm{W}_{8}$ in Attaqa, which are subjected to ships activities, whereas station $\left(\mathrm{W}_{9}\right)$ was found more polluted station $(W Q I=1.87)$ as a result of sewage flow at $\mathrm{W}_{9}$ station. The quality of waters of $\mathrm{W}_{10}$ was affected with many industrial effluents coming from Attaqa Company for Electricity and Miratex for Textile. $\mathrm{W}_{11}$ and $\mathrm{W}_{13}$ are subjected to domestic effluents of the Suez Government. Station $\mathrm{W}_{14}$ is located in port Tewfik Harbour that is affected with the activities of ships.

\section{Conclusion}

The present investigation gives some significant information about the ecological nature of the Gulf of Suez. The obtained results feature that, there is a pronounced variation in most of the water quality parameters with variation in season and geographic location. The water quality in the Gulf of Suez is influenced by the released from point wellsprings of contamination. The redesign spatial strategy of monitoring stations is required to assess the effect of hydro-advancement extends and assesses its impact on the studied area.

\section{Conflicts of Interest}

The authors declare no conflicts of interest regarding the publication of this paper.

\section{References}

[1] REMIP (2008) State of Oil Pollution and Management in Suez Gulf Region. A Re- 
port of Regional Environmental Management Improvement Project, 132 p.

[2] Frone, D.-F. and Frone, S. (2015) The Importance of Water Security for Sustainable Development in the Romanian Agri-Food Sector. Agriculture and Agricultural Science Procedia, 6, 674-681. https://doi.org/10.1016/j.aaspro.2015.08.120

[3] https://www.worldatlas.com/aatlas/infopage/gulfofsuez.htm

[4] Hamed, M.A., Soliman, Y.A., Khodir, A.E., Soliman, A.H., El-Agroudy, N.A. and Hussein, F. (2010) Physico-Chemical Characteristics of Suez Bay Water during 2006-2007. Egyptian Journal of Aquatic Biology and Fisheries, 14, 43-57. https://doi.org/10.21608/ejabf.2010.2051

[5] Emara, M.M., Farid, N.A., El-Sabagh, E.A., Ahamed, O.E. and Kamal, E.M. (2013) Physico-Chemical Study of Surface Seawater in the Northwestern Gulf of Suez. Egyptian Journal of Chemistry, 56, 345-365. https://doi.org/10.21608/ejchem.2013.1117

[6] Abdelmongy, A.S. and El-Moselhy, K.M. (2015) Seasonal Variations of the Physical and Chemical Properties of Seawater at the Northern Red Sea, Egypt. Open Journal of Ocean and Coastal Sciences, 2, 1-17.

[7] AboEl-Khair, A.M., Abdel Fattah, L.M., Abdel-Halim, A.M., Abd-Elnaby, M.A., Fahmy, M.A., Ahdy, H.H., et al. (2016) Assessment of the Hydrochemical Characteristics of the Suez Gulf Coastal Waters during 2011-2013. Journal of Environmental Protection, 7, 1497-1521. https://doi.org/10.4236/jep.2016.711126

[8] Khedr, A.I., Soliman, Y.A., El-Sherbeny, E.F., Hamed, M.A., Ahmed, M.A. and Goher, M.E. (2019) Water Quality Assessment of the Northern Part of Suez Gulf (Red Sea, Egypt), Using Principal Component Analysis. Egyptian Journal of Aquatic Biology and Fisheries, 23, 527-538. https://doi.org/10.21608/ejabf.2019.58410

[9] Strickland, J.D. and Parsons, T.R. (1972) A Practical Handbook of Seawater Analysis.

[10] Grasshoff, K., Kremling, K. and Ehrhardt, M. (1999) Methods of Seawater Analysis-Third Edition. Wiley-VCH Verlag GmbH, Weinheim, 203-223. https://doi.org/10.1002/9783527613984

[11] FAO (1976) Manual of Methods in Aquatic Environmental Research, Part I: Permanganate Value (Oxidizability) of Organic Matter in Natural Waters. FAO Fisheries Technical Paper No. 137, 169-174.

[12] APHA (1995) WPCF, Standard Methods for the Examination of Water and Wastewater. American Public Health Association/American Water Works Association/Water Environment Federation, Washington DC.

[13] Intergovernmental Oceanographic Commission (1983) Chemical Methods for Use in Marine Environment Monitoring.

[14] Koroleff, F. (1977) Simultaneous Persulfate Oxidation of Phosphorus and Nitrogen Compounds in Water. Report of the Baltic Intercalibration Workshop, 52-53.

[15] Valderrama, J.C. (1981) The Simultaneous Analysis of Total Nitrogen and Total Phosphorus in Natural Waters. Marine Chemistry, 10, 109-122. https://doi.org/10.1016/0304-4203(81)90027-X

[16] UNEP and PERSGA (1997) Assessment of Land-Based Sources and Activities Affecting the Marine Environment in the Red Sea and Gulf of Aden. UNEP Regional Seas Reports and Studies.

[17] DSME (2004) Decree of the State Minister of the Environment No. SI Annex III.

[18] Ruttenberg, K.C. and Dyhrman, S.T. (2005) Temporal and Spatial Variability of Dissolved Organic and Inorganic Phosphorus, and Metrics of Phosphorus Bioavai- 
lability in an Upwelling-Dominated Coastal System. Journal of Geophysical Research: Oceans, 110. https://doi.org/10.1029/2004JC002837

[19] Mackenzie, F.T., Ver, L.M. and Lerman, A. (2002) Century-Scale Nitrogen and Phosphorus Controls of the Carbon Cycle. Chemical Geology, 190, 13-32. https://doi.org/10.1016/S0009-2541(02)00108-0

[20] Chiaudani, G. and Vighi, M. (1978) Metodologia standard di saggioalgale per lo studio della contaminazione delle acque marine, quadrature. Instituto di Ricerca Sulle Acque, IRSA No. 39, 120.

[21] Dorgham, M.M., Abdel-Aziz, N.E., El-Deeb, K.Z. and Okbah, M.A. (2004) Eutrophication Problems in the Western Harbour of Alexandria, Egypt. Oceanologia, 46, 25-44.

[22] Håkanson, L. (1994) A Review on Effect-Dose-Sensitivity Models for Aquatic Ecosystems. Internationale Revue der Gesamten Hydrobiologie und Hydrographie, 79, 621-667. https://doi.org/10.1002/iroh.19940790412

[23] Primpas, I., Tsirtsis, G., Karydis, M. and Kokkoris, G.D. (2010) Principal Component Analysis: Development of a Multivariate Index for Assessing Eutrophication According to the European Water Framework Directive. Ecological Indicators, 10, 178-183. https://doi.org/10.1016/j.ecolind.2009.04.007

[24] Ignatiades, L., Karydis, M. and Vounatsou, P. (1992) A Possible Method for Evaluating Oligotrophy and Eutrophication Based on Nutrient Concentration Scales. Marine Pollution Bulletin, 24, 238-243. https://doi.org/10.1016/0025-326X(92)90561-J

[25] Lin, Y.C., Chang-Chien, G.P., Chiang, P.C., Chen, W.H. and Lin, Y.C. (2013) Multivariate Analysis of Heavy Metal Contaminations in Seawater and Sediments from a Heavily Industrialized Harbor in Southern Taiwan. Marine Pollution Bulletin, 76, 266-275. https://doi.org/10.1016/j.marpolbul.2013.08.027

[26] MacDonald, D.D., Smorong, D.E., Levy, D.A., Swain, L., Caux, P.Y. and Kemper, J.B. (2003) Canadian Water Quality Guidelines for the Protection of Aquatic Life. Canadian Council of Ministers of the Environment. 